\title{
Influence of social entrepreneurship pedagogical initiatives on students' attitudes and behaviours
}

\author{
Saidi Adedeji Adelekan \\ Mervywn Williamson \\ Sulaiman Olusegun Atiku \\ School of Management, Information Technology and Governance \\ University of KwaZulu-Natal, Westville Campus, Durban, South Africa
}

\begin{abstract}
Keywords
Behavioural intention, behavioural outcomes, educational contents, planned behaviour, social entrepreneurs, ventures creation
\end{abstract}

\begin{abstract}
This study examines the influence of social entrepreneurship pedagogy on the behavioural outcomes of the Nigerian universities' students; regarding their attitudes, intentions and behaviours towards social venture creation. The Nigeria university system is producing graduates as employees rather than employers of labour. Insights were drawn from the theory of planned behaviour and theory ' $U$ ' in this inquiry. The principles of quantitative and correlational methods were combined in an explanatory research design. The multivariate statistical analyses used in this study are exploratory and confirmatory factor analyses, structural equation modelling as well as model fit indices. The results point to a significant positive relationship between social entrepreneurial pedagogy and students behavioural outcomes in the Nigerian universities. Results also show that pedagogical contents exert the greatest influence on students' intentions towards creating social ventures. Students' attitudes mediate the relationship between social entrepreneurial pedagogy and students' behavioural outcomes in Nigeria.
\end{abstract}

Corresponding author: Sulaiman Olusegun Atiku

Email addresses for corresponding author: atiku@ukzn.ac.za

First submission received: $30^{\text {th }}$ June 2017

Revised submission received: $12^{\text {th }}$ October 2017

Accepted: $3^{\text {rd }}$ November 2017

\section{Introduction}

Recently, there has been enthusiasm for promoting and increasing entrepreneurial orientation to support the idea of social entrepreneurship to increase self-employment awareness among students globally. The significance of education in enhancing development of new businesses is perceived by both professionals and researchers (Babwah-Ramkissoon, 2012; Cholil, 2015; Schwarz \& Wdowiak, 2006). Entrepreneurship education is a valuable tool in advancing social venture creation. The restructuring procedures in organisations around the world shows a downward trend in graduates employability. Specifically, the unemployment levels among graduates in Nigeria have reached an alarming propensity, especially in recent years. The Nigerian Government has recently introduced social entrepreneurship education in the university curriculum as part of its initiative to promote self-employment. The primary aim of this initiative was to provide graduates with adequate social entrepreneurial skills to improve employability in the labour market. The initiative is targeted at reducing the associated social problems in the Nigerian society. Social enterprise as a field of study in business sciences and entrepreneurship courses for students of technical studies are necessary to reduce the high rate of unemployment.

As a result of declining employment opportunities across the globe, entrepreneurship education can be used to revitalise undergraduates' self-efficacy and entrepreneurial mind-sets (Günzel-Jensen, Moberg, Mauer \& Neergaard, 2017). Recently, a study explores the place of successful entrepreneurs as role models in shaping students attitudes towards entrepreneurial activities (Fellnhofer \& Puumalainen, 2017). The study found that entrepreneurial attitudes can be shaped through constructive interactions with successful entrepreneurs. Therefore, the environment and individuals' qualities drive the students towards self-employment. This submission is based on the empirical investigation conducted in Austria, 
Finland and Greece. The African contexts of the studies on pedagogical initiatives and undergraduates' behaviours towards entrepreneurial intention is lacking, especially in Nigeria. There is a dearth of empirical evidence regarding the influence of pedagogical contents and techniques on students' behavioural outcomes in Nigeria.

The primary objective of this study is to examine the influence of pedagogical contents and techniques (social entrepreneurship education) on students' behavioural outcomes in selected Nigerian universities. Specifically, this study seeks to explore the mediating influence of students' attitudes on the relationship between social entrepreneurship education and behavioural outcomes (students' intentions and behaviours) towards setting up social ventures.

\section{Review of Literature}

This section examines the literature to gain insights on the influence of social entrepreneurship interventions on attitude and behaviour towards establishing a social venture.

\subsection{Entrepreneurship pedagogy}

The introduction of entrepreneurship pedagogy in the university curriculum is basically to inculcate the entrepreneurial orientations into the minds of students. Entrepreneurship pedagogy refers to the approaches and philosophies of teaching entrepreneurship (Moses \& Akinbode, 2014). Entrepreneurship pedagogy enhances the students' entrepreneurial mind-sets and the ability to take advantage of new business opportunities in their environments (Hussain \& Norashidah, 2015). Hussain and Norashidah (2015) found that entrepreneurial mind-sets and knowledge of social network is fundamental for teaching and establishing social ventures. Entrepreneurship education plays a significant role in building confidence towards establishing social ventures (Wilson, Kickul \& Marlino, 2007). The empirical study conducted by Bae, Qian, Miano and Fiet (2014) shows a positive relationship between entrepreneurship pedagogy and entrepreneurial intention. Furthermore, student's exposure to entrepreneurial activities or background and entrepreneurship education can produce a positive influence on an individual's intention to become an entrepreneur (Fayolle \& Gailly, 2015). Lourenço, Jones and Jayawarna (2013) found that perceived usefulness of entrepreneurship pedagogy is effective in promoting sustainable development. The entrepreneurial knowledge will assist students in conducting proper feasibility study before committing their working capital into operations. Therefore, effective transfer of entrepreneurial knowledge depends on the adopted pedagogical contents and techniques, as well as the instructor's theoretical and practical experiences. Moses and Akinbode (2014) proposed the need to design a captivating pedagogical content in order to draw students' attentions into entrepreneurship education in Nigeria. However, there is a paucity of empirical analysis showcasing the influence of entrepreneurship pedagogy on students' attitudes and behaviours towards establishing social ventures in Nigeria. The current study seeks to fill this gap by conducting an empirical analysis.

\subsection{Entrepreneurial Attitude}

Attitude is one the major individuals attributes influencing the decision to start up a new venture. The other essential orientations influencing social entrepreneurial intention and behaviour are the need for success, risk-taking ability, the internal locus of control, and creativity (Bagheri \& Pihie, 2014; Hussain \& Norashidah, 2015). Again the personality approaches are with critics (Ahmed, 2012; Robinson et al., 1991). From the 1990s, the attitude approach has become a benchmark and widely used in predicting the likelihood to establish an enterprise, as an alternative to the personality theories (Ahmed 2012; Douglas 1999). According to the theory of planned behaviour, attitude has an impact on intention and behaviour. Specifically, there are three key fundamental attitudinal precursors of intention; perceived social norm, perceived behavioural control and personal attitude towards outcomes of the behaviour (Chun-Mei et al., 2011; Karimi, 2012). The attitudinal precursors have proven to account for a significant part of the variance in intention (Karimi, 2012).

Attitudes are moderately less steady than personality traits and can be changed over time or influenced by the interaction of individuals with the environment (Izquierdo \& Buelens, 2011; Robinson et al. 1991). Instructors and practitioners can influence social entrepreneurial attitudes. Robinson et al., (1991) emphasise the need to differentiate between general attitudes related to the broad psychological disposition of an individual. Accordingly, the domain referring to the right attitudes towards creating a 
new venture must be contextualised. The application of a particular approach raises the accuracy of the measurement within the predefined domain.

The significance of attitudes towards creating a new social venture, has been recognized and empirically verified in previous studies (Aslam, Awan \& Khan, 2012; Douglas 1999; Karimi, 2012; Krueger et al., 2000; Izquierdo \& Buelens, 2011). Accordingly, the empirical discoveries on the direction and importance of the attitude-intent relationships is partly inconsistent. The focus is predominately directed on empirical studies addressing entrepreneurial aspirations among students to draw conclusions from a model suitable for university students (Williams \& Williams, 2014).

\subsection{Entrepreneurial Attitude and Intention}

There is need to showcase the relationship between entrepreneurial attitude and intention to start one's business (Douglas, 1999). Douglas found that people with a more positive attitude towards freedom and risk are characterised by a higher willingness to become entrepreneurs. Individuals' attitudes to work endeavours negatively correlate with the intention to become an entrepreneur. In spites of Douglas's findings, Wang and Wong (2004) discovered a non-significant impact of risk-averse attitudes on entrepreneurial interests. Franke and Lu"thje (2004) found a positive relationship between perception and attitude towards self-employment and intention to become an entrepreneur. Lu"thje and Franke (2003) analysed the effect of individual beliefs and perceived environmental conditions for establishing a new venture in a survey of students of technical disciplines at the Massachusetts Institute of Technology. The study found that the attitude towards entrepreneurship is the most important determinant of entrepreneurial intention.

\subsection{Theoretical Framework}

The theory of planned behaviour and theory ' $U$ 'were adopted as theories underpinning this study. The theory of planned behaviour was developed by Ajzen (1991), and was adopted by researchers to predict individuals' attitudes, intentions and behaviours. The theory states that intentions depend on attitudes towards the attractiveness of behaviours, subjective norms (which is social expectation) and perceived behavioural control. The theory holds that a person's intention to perform a particular action will increase with his perceived behavioural control. The theory of planned behaviour is adopted in this study to explain students' attitudes, intentions, and behaviours towards social venture creation. However, this implies that students will attempt to start a new venture if they believe that they have the right abilities to succeed.

Theory ' $U$ ' was propounded in 1968 by Friedrich Glasl and Dirk Lemon (Scharmer, 2007). The theory was later improved on by Otto Scharmer in the early 1980s and presented systematically in 2000s. The theory explains how students' behavioural patterns can be enhanced through practical orientations (pedagogical contents and techniques). This study considers these approaches as the appropriate theoretical framework to investigate the influence of social entrepreneurship initiatives on students' attitudes and other behavioural outcomes in selected Nigerian universities. The conceptual framework derived from the theories is diagrammatically illustrated in Figure 1.

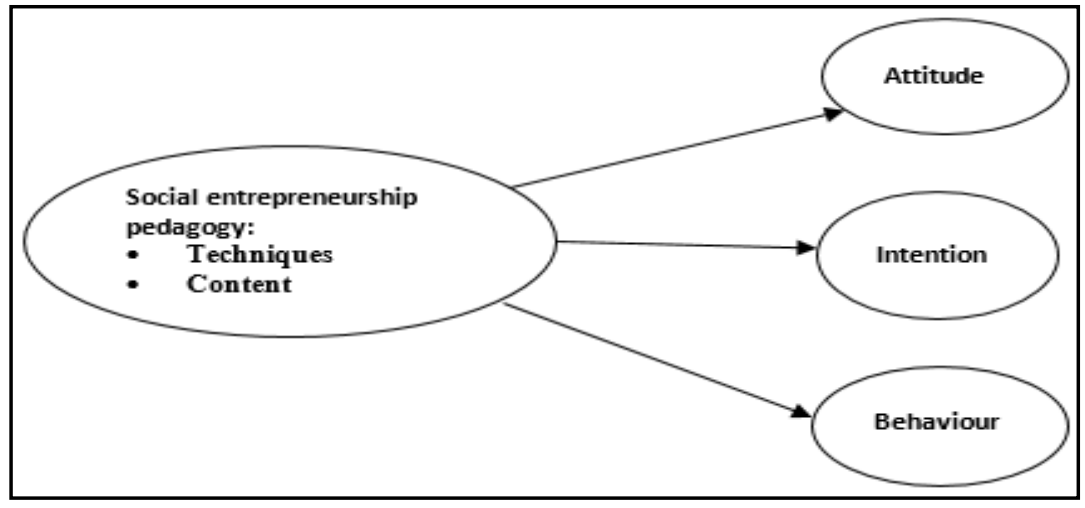

Fig. 1. The influence of entrepreneurship pedagogy on students' behavioural outcomes 


\subsection{Model Specification and Hypotheses}

As diagrammatically presented in Figure 1, social entrepreneurship pedagogy can be referred to as the primary exogenous latent variable investigated in this study. Pedagogical contents and techniques are the corresponding exogenous manifest variables. Students' attitudes, intentions, and behaviours are the endogenous latent variables. Based on the conceptual framework, this study hypothesised:

H1: A significant positive relationship between social entrepreneurship pedagogy and students' behavioural outcomes in selected Nigerian universities.

H2: Students' attitudes mediate the relationship between social entrepreneurship pedagogy and students' behavioural outcomes.

H3: A significant positive relationship between social entrepreneurship pedagogy and students' intentions towards creating a social venture.

\section{Methodology}

This study adopted a quantitative approach to investigate the influence of social entrepreneurship pedagogy on students' attitudes, intentions, and behaviours towards social venture creation in selected Nigerian universities. The population of this study comprised the final year students (400 level students) in the Faculty of Management Sciences at the selected universities in Nigeria. The target population of this survey is 3,777 undergraduates. A sample size of 367 was drawn from the target population. The three (3) randomly selected Nigerian universities offered Business Creation and Growth; Issues of Business Growth; Sources of Funds; and Entrepreneurial Marketing modules in the Faculty of Management Sciences. Data was collected through the use of a structured questionnaire to elicit information regarding the influence of social entrepreneurship initiatives on perceived attitudes and behaviours towards venture creation. The respondents were the final-year students in the Faculty of Management Sciences at the Lagos State University, Babcock University, and the University of Lagos, Nigeria. The structure of the questionnaire includes demographic section, social entrepreneurship education, students' attitudes, intentions and behaviours towards social venture creation.

\subsection{Measures}

Social Entrepreneurship Pedagogy: The construct social entrepreneurship pedagogy was adapted from Smith and Woodworth (2012). The first dimension adapted was designed to measure the pedagogical techniques used by instructors in teaching social entrepreneurship in selected Nigerian universities. Items 1 to 7 of the pedagogical technique was developed in line with a 5-point Likert's type ratings, ranging from strongly disagree (1) to strongly agree (5). The second dimension measures pedagogical contents adopted by lecturers in communicating social entrepreneurial orientations to learners in selected Nigerian universities. Items 1 to 10 were designed accordingly, ranging from strongly disagree (1) to strongly agree (5). The Cronbach's alpha coefficients of the exogenous manifest variables (pedagogical contents and techniques) are provided after the exploratory factor analysis.

Behavioural Outcomes: The construct students' behavioural outcomes were assessed adapting three dimensions of the theory of planned behaviour developed by Ajzen (1991; 2013). The first dimension measures student attitudes towards social entrepreneurship using items 1 to 8 on a 5-point Likert's type rating scale. The second dimension of behavioural outcomes scale measures students' intentions towards social entrepreneurship in Nigerian universities. Items 1 to 8 were used to elicit students' intentions on a 5 -point Likert's type rating scale. The third dimension on this scale was used to measure students' social entrepreneurship behaviours, regarding their entrepreneurial capacities in the Nigerian universities. Items 1 to 6 were raised to elicit information on students' entrepreneurial capabilities using a 5-point Likert's type rating scale. The dimensional Cronbach's alpha coefficients are presented after the exploratory factor analysis in the data analysis section.

\subsection{Data Analysis Procedures}

The IBM Statistical Package for the Social Sciences (SPSS, version 24) is valuable in performing the preliminary analysis, such as data screening and filling up the missing data, checking for outliers using Mahalanobis distance, Cook's distance and leverage values. To avoid violation of multicollinearity assumptions, the researchers subjected the variables to Pearson's bivariate correlation coefficients. Normal probability plot was assessed using multiple regression analysis, the tolerance $(<1)$ and VIF $(<10)$ values in the coefficients table; reaffirm non-violation of multicollinearity assumptions. Exploratory Factor 
Analysis (EFA) was conducted to validate the key factors by selecting a maximum likelihood option using an Oblique Promax Rotation method in SPSS. The internal consistency of the key factors extracted from the EFA was assessed using Cronbach's alpha coefficients. According to the rule of thumb guiding preliminary analyses provided by Pallant (2011), no statistical assumption was violated in this study. The IBM Analysis of Moment Structure (AMOS Graphics, version 24) was used in running structural equation modelling (SEM). This is essential to provide adequate explanations concerning the influence of pedagogical contents and techniques on students' behavioural outcomes towards social venture creation in Nigeria. The model fit indices used to assess the fitness of Confirmatory Factor Analysis (CFA) and structural models in this study are the chi-square value, degree of freedom and P values. The normed chisquare test values are useful in determining model fit, which is the chi-square value - degree of freedom ratio (Hooper, Coughlan \& Mullen, 2008). Three incremental model fit indices used are the Tucker-Lewis Index (TLI), the Incremental Fit Index (IFI) and the Comparative Fit Index (CFI). The values for Gross Fit Index (GFI) and Root Mean Square Error of Approximation (RMSEA) and PCLOSE were also reported in this study to examine the fitness of proposed model to the sample data.

\section{Results and Discussion}

Illustrated in Tables 1 and 2, are the psychometric properties of the research instrument used in assessing the influence of instructors' entrepreneurial initiatives on students' behavioural outcomes in the Nigerian universities. Also presented with the EFA are the descriptive statistics, item-total correlations, Cronbach's alpha coefficients, eigenvalues, and variances explained by the extracted factors.

Table 1: Psychometric properties of the research instrument

\begin{tabular}{|c|c|c|c|c|c|c|c|c|}
\hline \multirow{2}{*}{ Items } & \multicolumn{5}{|l|}{ Factor } & \multirow{2}{*}{ Mean } & \multirow{2}{*}{$S D$} & \multirow{2}{*}{$\begin{array}{l}\text { Item Total } \\
\text { Correlation }\end{array}$} \\
\hline & 1 & 2 & 3 & 4 & 5 & & & \\
\hline IN5 & .866 & & & & & 4.03 & .940 & .510 \\
\hline IN6 & .857 & & & & & 3.98 & .929 & .593 \\
\hline IN4 & .774 & & & & & 3.99 & .941 & .665 \\
\hline IN3 & .716 & & & & & 3.70 & 1.032 & .543 \\
\hline IN2 & .670 & & & & & 3.75 & 1.081 & .578 \\
\hline IN1 & .600 & & & & & 3.63 & 1.081 & .585 \\
\hline IN8 & .571 & & & & & 4.00 & .958 & .531 \\
\hline IN7 & .450 & & & & & 4.31 & .860 & .422 \\
\hline PC3 & & .638 & & & & 3.42 & 1.078 & .412 \\
\hline PC10 & & .637 & & & & 3.55 & 1.052 & .496 \\
\hline PC 8 & & .624 & & & & 3.61 & .982 & .392 \\
\hline PC2 & & .621 & & & & 3.41 & 1.057 & .457 \\
\hline PC7 & & .612 & & & & 3.43 & 1.099 & .356 \\
\hline PC 6 & & .582 & & & & 3.68 & .985 & .458 \\
\hline PC9 & & .544 & & & & 3.54 & 1.073 & .367 \\
\hline PC5 & & .537 & & & & 3.83 & .973 & .370 \\
\hline PC1 & & .531 & & & & 3.39 & 1.149 & .471 \\
\hline PC 4 & & .484 & & & & 3.83 & .888 & .451 \\
\hline BE3 & & & .874 & & & 3.77 & .974 & .596 \\
\hline BE5 & & & .816 & & & 3.80 & .934 & .494 \\
\hline BE2 & & & .751 & & & 3.77 & .947 & 609 \\
\hline BE6 & & & .725 & & & 3.95 & .903 & .534 \\
\hline BE4 & & & .694 & & & 4.01 & .868 & .638 \\
\hline BE1 & & & .622 & & & 3.79 & .985 & .651 \\
\hline AT4 & & & & .830 & & 3.91 & .873 & .539 \\
\hline AT3 & & & & .796 & & 4.03 & .891 & .521 \\
\hline AT2 & & & & .750 & & 3.84 & .944 & .530 \\
\hline AT5 & & & & .590 & & 3.77 & .969 & .448 \\
\hline AT1 & & & & .513 & & 3.79 & 1.002 & .518 \\
\hline AT7 & & & & .499 & & 4.19 & .904 & .373 \\
\hline AT6 & & & & .389 & & 3.74 & 1.001 & .481 \\
\hline PT3 & & & & & .765 & 3.87 & .944 & .397 \\
\hline
\end{tabular}




\begin{tabular}{lllll} 
PT2 & .638 & 3.79 & 1.018 & .363 \\
PT4 & .489 & 3.84 & .962 & .291 \\
PT7 & .318 & 3.72 & 1.012 & .357 \\
\hline
\end{tabular}

Table 2: Statistical outputs: Psychometric properties of the research instrument

\begin{tabular}{cccccc}
\hline Statistical tool & 1 & 2 & Factor & 4 & 5 \\
\hline Cronbach's a & .887 & .839 & .900 & .827 & .701 \\
Eigenvalue & 10.1 & 3.2 & 1.9 & 1.8 & 1.6 \\
Variance $(\%)$ & 28.8 & 9.2 & 5.6 & 5.0 & 4.7 \\
\hline
\end{tabular}

${ }^{*} \mathrm{KMO}=0.908 ; \mathrm{X}^{2}=5858.436 ; \mathrm{DF}=595 ; \mathrm{P}<0.001 ;$ Total variance explained $=53.3 \%$.

As presented in Table 1, the first factor extracted measures students' intentions to start up new social venture. Factor 1 (intention), explained 28.8 percent of the total variance $(53.3 \%$ ) explained as illustrated in Table 2. The internal consistency of items 1 to 8 used to measure students' intentions is 0.887 ; one can infer that the scale is reliable based on the rule of thumb (Field 2005; Pallant, 2011). The second factor extracted is pedagogical contents adopted by instructors in selected Nigerian universities. The pedagogical contents explained 9.2 percent of the variations and produced a reliable Cronbach's alpha coefficient of 0.839 . The third factor extracted explained 5.6 percent of the variance in students' behaviour in selected Nigerian universities. The internal consistency of the six items factor produced an excellent (reliable) Cronbach's alpha coefficient of 0.900 in Nigeria. The fourth factor illustrated in Table 1, explained 5.0 percent variance by measuring students' attitudes towards social entrepreneurship. The $8^{\text {th }}$ item was deleted on the scale for cross loading during the EFA. The remaining seven items measure of students' attitudes towards social entrepreneurship yielded a reliable Cronbach's alpha coefficient of 0.827 . The fifth factor explained 4.7 percent variance by measuring the pedagogical techniques used by instructors in teaching social entrepreneurship. Items one (1), five (5) and six (6)were deleted during statistical analysis, while the remaining four items yielded an acceptable Cronbach's alpha coefficient of 0.701. The Kaiser-Meyer-Olkin (KMO) value of 0.908 indicates a superb sample size (367) adequacy (Field, 2005). The Bartlett Test of Sphericity is highly significant $(\mathrm{P}<0.001)$, which shows that EFA is appropriate (Field, 2005; Pallant, 2011). The CFA model is presented in Figure 2.

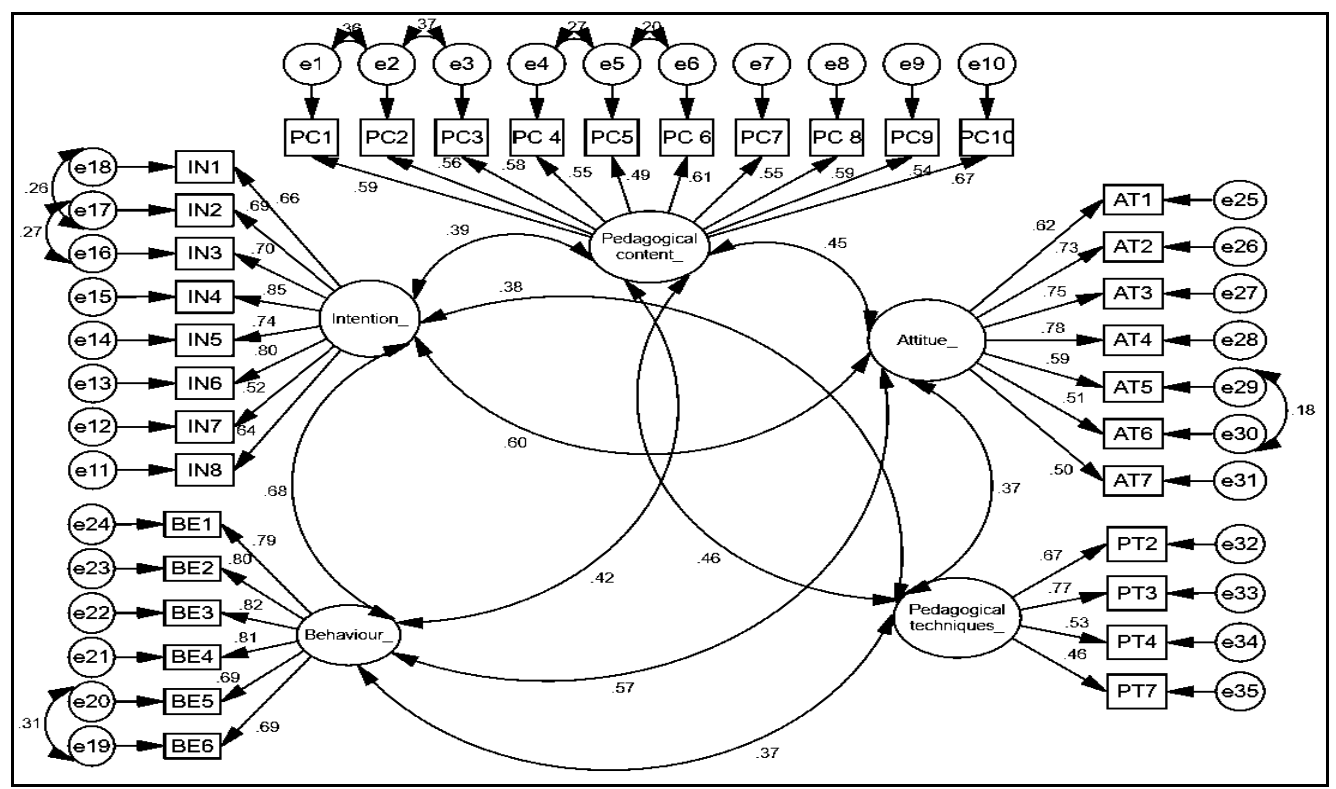

Chi-square = 941.392; $\mathrm{DF}=542 ; \mathrm{p}$-value $=0.000(<0.001) ; \mathrm{CMIN} / \mathrm{DF}=1.737(<5) ; \mathrm{GFI}=0.912(>0.90) ; \mathrm{IFI}$ $=0.928(>0.90) ; \mathrm{TLI}=0.920(>0.90) ; \mathrm{CFI}=0.927(>0.90) ; \mathrm{RMSEA}=0.045$ (below 0.05); PCLOSE $=.962(>$ $0.5)$

Fig. 2. Confirmatory factor analysis for social entrepreneurial education and students' behavioural outcomes 
According to the model fit indices shown in Figure 2, this study concludes that the hypothesised 5-factor CFA model is well fitted to the sample data. As indicated by a CFI value of 0.927, and RMSEA value of 0.045 ; which is within the acceptability range (Byrne, 2010). All factors loadings are significant ( $\mathrm{p}$ $<0.001$ ) and ranged from 0.459 to 0.821 . The factors loadings suggest a statistical validity of the proposed model. The fit indices validate the theoretical foundation of the five latent variables (represented by circles in Fig. 2) and their corresponding manifest variables (represented by boxes in Fig. 2). This empirical model validates the theoretical propositions concerning the influences of pedagogical contents and techniques on students' behavioural outcomes such as attitude, intention, and behaviour in selected Nigerian universities. The structural model explaining the importance of social entrepreneurship initiatives on students' behavioural outcomes in Nigeria is presented in Figure 3.

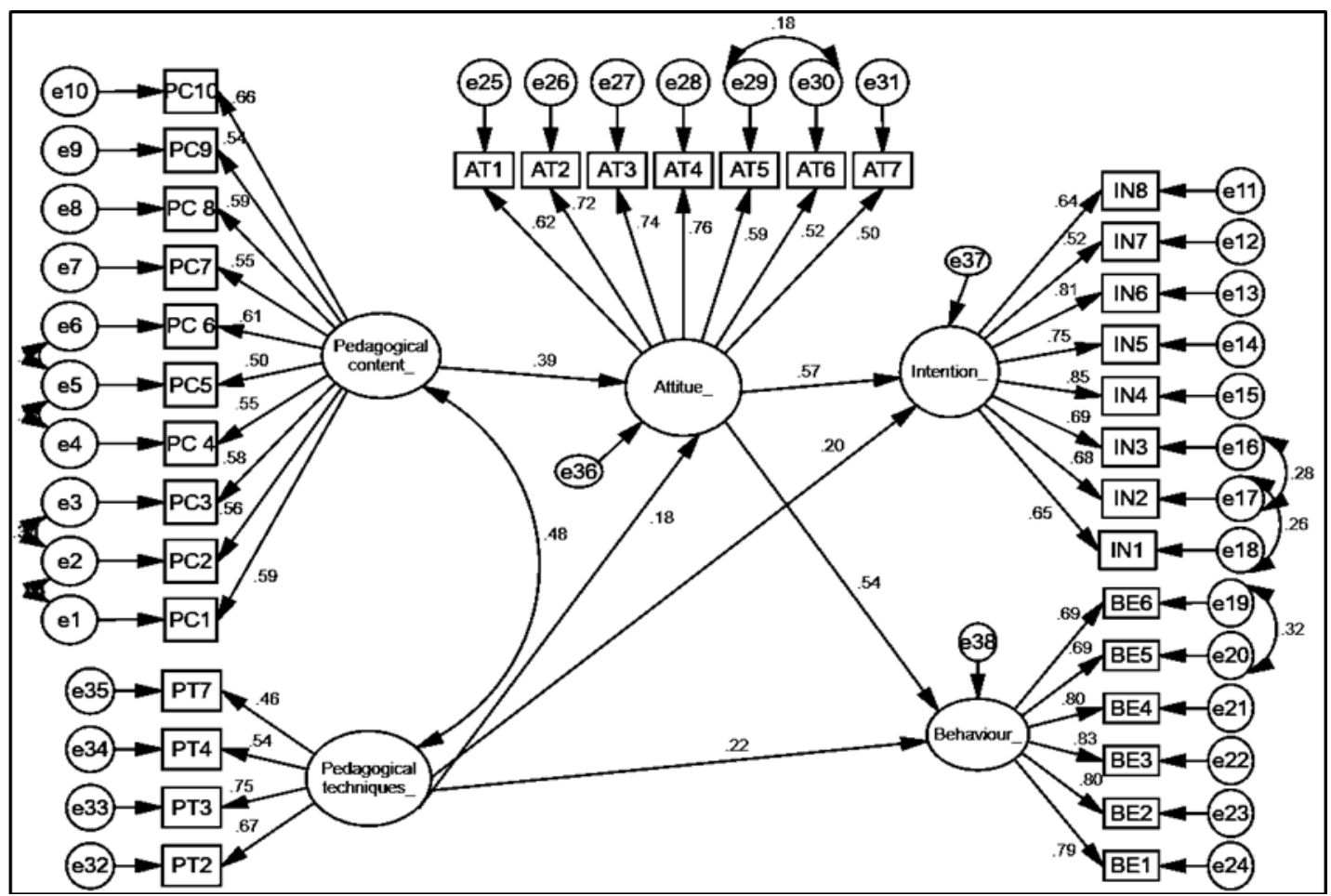

Chi-square = 1004.951; $\mathrm{DF}=545 ; \mathrm{p}$-value $=0.000(<0.001) ; \mathrm{CMIN} / \mathrm{DF}=1.844(<5) ; \mathrm{GFI}=0.906(>0.90) ; \mathrm{IFI}$ $=0.917(>0.90) ; \mathrm{TLI}=0.908(>0.90) ; \mathrm{CFI}=0.916(>0.90) ; \mathrm{RMSEA}=0.048$ (below 0.05); PCLOSE $=.755(>$

$0.5)$.

Fig. 3. Structural model of entrepreneurial pedagogy and students' behavioural outcomes

The model fit indices presented in Figure 3 suggest an acceptable fit to the sample data in selected Nigerian universities. Statistically, all beta and factor loadings are significant. The standardized direct effect of pedagogical contents on students' attitudes is $0.39, \mathrm{p}=0.001$. Empirically, when pedagogical content goes up by one (1) standard deviation, students' attitudes increase by 0.39 points. This result signifies a significant positive relationship between pedagogical contents (PC) and students' attitudes towards social entrepreneurship in Nigerian universities. The standardised direct effect of pedagogical techniques on students' attitudes is $0.18, \mathrm{p}=0.030$. Statistically, a unit increase in the standard deviation of pedagogical technique results in 0.18 increase in students' attitudes towards social entrepreneurship. There is a positive relationship between pedagogical techniques and students' attitudes towards social entrepreneurship in Nigeria. The results show that pedagogical contents and techniques as measures of entrepreneurship initiatives by instructors in Nigerian universities positively influenced students' attitudes $(\mathrm{PC}=0.39, \mathrm{p}=0.001 ; \mathrm{PT}=0.18, \mathrm{p}=0.030$ ) towards starting up a social venture. This empirical evidence shows that pedagogical content exerts a more significant indirect positive effects on students' intentions $(0.57, \mathrm{p}=0.002)$ and behaviours $(0.54, \mathrm{p}=0.002)$ towards social entrepreneurship in the Nigerian universities. This study also found significant standardized direct effects of pedagogical 
techniques on students' intentions $(0.20, \mathrm{p}=0.001)$ and behaviours $(0.22, \mathrm{p}=0.005)$ towards social entrepreneurship in Nigeria. These findings showed significant positive relationships between social entrepreneurial education and students' behavioural outcomes in selected Nigerian universities; as such, hypothesis one (H1) is supported. The outcomes of this empirical analysis corroborate the results of previous studies (Karimi, 2012; Souitaris et al., 2007) that social entrepreneurship training significantly influenced attitudes, intentions, and behaviours of students in higher education.

The standardiseddirect effects of pedagogical contents on students' intentions and behaviours towards social entrepreneurship were insignificant. The level of insignificance is confirmed using a bootstrap two-tailed significant test on AMOS graphics, version 24. Therefore, students' attitudes fully mediate the relationships between pedagogical contents and students' intentions, likewise students' behaviours towards social entrepreneurship. Hypothesis two (H2) is supported on the ground that students' attitudes fully mediate the relationship between pedagogical content as a measure of social entrepreneurship education and other behavioural outcomes (students' intentions and behaviours). The standardised indirect (partially mediated by students' attitudes) effects of pedagogical techniques on students' intentions $(0.57, \mathrm{p}=0.031)$ and behaviours $(0.54, \mathrm{p}=0.031)$ towards social entrepreneurship are significant. These findings support the second hypothesis $(\mathrm{H} 2)$ and also corroborate the previous studies (Izquierdo \& Buelens, 2011; Wu \& Wu, 2008). The only exception is that students' attitudes partially mediated the interplay between pedagogical techniques and other behavioural outcomes (students' intentions and behaviours) in Nigeria.

Regarding the direction of association between social entrepreneurship education and students' intentions towards creating a social venture. This study found that social entrepreneurship pedagogy exerts a strong positive indirect effect on students' intentions $(0.57, \mathrm{p}=0.031)$ through students' attitudes. Empirically, entrepreneurship pedagogical contents $(0.39, \mathrm{p}=0.001)$ exert more positive influence on students' intentions through students' attitudes, when compared to entrepreneurship pedagogical techniques $(0.18, p=0.030)$. These results support hypothesis three $(\mathrm{H} 3)$ because there is a significant positive relationship between social entrepreneurship pedagogical initiatives and students' intentions toward creating a social venture. It is also in tandem with the findings of Kristiansen and Indarti (2004), as well as Mars and Garrison (2009) submission.

\section{Conclusion and Recommendations}

This study investigated the influence of social entrepreneurship pedagogy on students' attitudes, intentions, and behaviours in selected Nigerian universities. Based on the empirical evidence reported in the measurement and structural models, this study submits that social entrepreneurship education has a positive and statistically significant effect on undergraduates behavioural outcomes. The pedagogical initiatives introduced by the universities offering entrepreneurial modules significantly influenced undergraduates' attitudes, intentions, and behaviours towards social venture creation in Nigeria. Based on the pedagogical contents and techniques exposed to during schooling, graduates that have passed through entrepreneurial modules should showcase their abilities to venture into social entrepreneurial activities. This study also revealed that social entrepreneurship education has a strong, positive, and statistically significant effect on students' intentions to start up a new social venture. This study concludes that students' attitudes, intentions, and behaviours are crucial in predicting social entrepreneurial aspirations of students.

To enhance students' attitudes, intentions and behaviours towards venture creation, this study recommends that universities should interact with supportive organisations, such as banks and incubation centres. Putting the right structures and incubation centres in place would help in enhancing social entrepreneurial intentions among potential social entrepreneurs in Nigeria. More so, pedagogical contents and techniques of social entrepreneurship interventions need to be augmented such that there will be a linkage between town and gown. Lastly, the government also has a role to play in enforcing conducive environments for developing social entrepreneurs, by facilitating the delivery of required infrastructural facilities in the Nigerian universities.

\section{Limitation and Future Research Direction}

The findings reported in this study are restricted to the influence of social entrepreneurship pedagogy on students' behavioural outcomes in selected universities in Nigeria. The psychological states 
of students regarding self-efficacy, and social identity were not measure or reported in this study. Future studies may consider the use of the psychological state as a mediator between social entrepreneurship education and students' behavioural outcomes. Most importantly, this study is credible in showcasing the moderating influence of students' attitudes on the interplay between social entrepreneurship education and students' behavioural outcomes with the use of structural equation modelling.

\section{References}

Ahmed, S. (2012). Sigmund Freud's psychoanalytic theory Oedipus complex: A critical study with reference to DH Lawrence'sSons and Lovers. Internal Journal of English and Literature, 3(3). 60-70.

Ajzen, I. (1987). Attitudes, traits, and actions: Dispositional prediction of behaviour in personality and social psychology. Advances in experimental social psychology, 20, 1-63.

Ajzen, I. (1991).Theory of planned behaviour. Organisational Behaviour and Human Decision Processes, 50, 179-211.

Aldrich, H. E., Zimmer, C. (1986). Entrepreneurship through social networks. In: HE Aldrich (Ed.): Population Perspectives on Organisations. Uppsala: Acta Universitatis Upsaliensis, pp. 13-28.

Ajzen, I. (2013). Theory of planned behaviour questionnaire. International Journal of Communication and Management, 21(1), 8-12.

Aslam, T.; Awan, A., \& Khan, T. (2012). Entrepreneurial intentions among University students of Punjab a province of Pakistan. International Journal of Humanity and Social Sciences, 2(14), 114-120.

Ramkissoon-Babwah, N. (2012). An entrepreneurship education model for Trinidad and Tobago. Journal of Emerging Trends in Educational Research and Policy Studies, 3(3), 307-311.

Bae, T. J.; Qian, S., Miao, C., \& Fiet, J. O. (2014). The relationship between entrepreneurship education and entrepreneurial intentions: A meta-analytic review. Entrepreneurship Theory and Practice, 38(2), 217-254.

Bagheri, A. Pihie, Z. A. L. (2014). The Factors Shaping Entrepreneurial Intentions. Cambridge Scholars Publishing.

Byrne, B. M. (2010). Structural equation modelling with AMOS: Basic concepts, applications, and programming. ( $2^{\text {nd }}$ ed). New York, NY: Routledge Taylor \& Francis Group.

Cholil, M. (2015). Analysis of attitude, experience, subjective norm and behavioural control on the entrepreneurial intention and behaviour: A case study toward the Pawners of Sharia Pawnshop of Surakarta Branch Office, Central Java, Indonesia. International Journal of Information, Business and Management, 7(2), 63-74.

Chun-Mei, C. H. O. U., Chien-Hua, S. H. E. N., \& HSIAO, H. C. (2011). The Influence of Entrepreneurial Self-Efficacy on Entrepreneurial Learning Behaviour-Using Entrepreneurial Intention as the Mediator Variable. International Business and Management, 3(2), pp. 7-11.

Douglas, E. J. (1999). Entrepreneurship as a career choice: Attitudes, entrepreneurial intentions, and utility maximization. Frontiers of Entrepreneurship Research. Wellesley, MA: Babson College.

Fayolle, A., \& Gailly, B. (2015). The impact of entrepreneurship education on entrepreneurial attitudes and intention: Hysteresis and persistence. Journal of Small Business Management, 53(1), 75-93.

Field, A. P. (2005). Discovering Statistics using SPSS ( $2^{\text {nd }}$ ed). Sage, London.

Franke, N., \& Lüthje, C. (2004). Entrepreneurial intentions of business students - A benchmarking study. International Journal of Innovation and Technology Management, 1(3), 269-288.

Fellnhofer, K., Puumalainen, K. (2017). Can role models boost entrepreneurial attitudes? International Journal of Entrepreneurship and Innovation Management, 21(3), 274-290.

Günzel-Jensen, F.; Moberg, K., Mauer, R., Neergaard, H. (2017). Self-Efficacy and the Entrepreneurial Mindset Revisited. In Revisiting the Entrepreneurial Mind (pp. 319-335). Springer International Publishing.

Hooper, D., Coughlan, J., Mullen, M. (2008). Structural equation modelling: Guidelines for determining model fit. Articles, 6(1), 53-60.

Izquierdo, E., \& Buelens, M. (2011). Competing models of entrepreneurial intentions: the influence of entrepreneurial self-efficacy and attitudes. International Journal of Entrepreneurship and Small Business, 13(1), 75-91. 
Karimi, S., Biemans, H. J., Lans, T., Mulder, M., \& Chizari, M. (2012). The role of entrepreneurship education in developing students' entrepreneurial intentions.

https://www.researchgate.net/profile/Saeid_Karimi2/publication/256035382_The_Role_of_Entreprene urship_Education_in_Developing_Students'_Entrepreneurial_Intentions/links/00b49524c952c9fda b000000.pdf

Kristiansen, S., \& Indarti, N. (2004). Entrepreneurial intention among Indonesian and Norwegian students. Journal of Enterprising Culture, 12(1), 55-78.

Krueger, N. F., Reilly, M. D., \& Carsrud, A. L. (2000). Competing models of entrepreneurial intentions. Journal of business venturing, 15(5), 411-432.

Lourenço, F., Jones, O., \& Jayawarna, D. (2013). Promoting sustainable development: The role of entrepreneurship education. International Small Business Journal, 31(8), 841-865.

Mars, M. M., \& Garrison, S. (2009). Socially-oriented ventures and traditional entrepreneurship education models: a case review. Journal of Education for business, 84(5), 290-296.

Moses, C., \& Akinbode, M. (2014). Entrepreneurship Curriculum and Pedagogical Challenges in Captivating Students' Interest towards Entrepreneurship Education. Research Journal of Economics and Business Studies, 4(1), 1-10.

Pallant, J. (2011). SPSS survival manual: A step by step guide to data analysis using SPSS. (4 ${ }^{\text {th }}$ ed.). Perth: Allen and Unwin.

Raijman, R. (2001). Determinants of entrepreneurial intentions: Mexican immigrants in Chicago. The Journal of Socio-Economics, 30(5), 393-411.

Robinson, P. B., Stimpson, D. V., Huefner, J. C., \& Hunt, H. K. (1991). An attitude approach to the prediction of entrepreneurship. Entrepreneurship theory and practice, 15(4), 13-31.

Schemar, S. L. (2007). Theory U: Leading from the future as it emerges. Cambridge: M.A

Schwarz, E. J., \& Wdowiak, M. A. (2006). New venture performance in the transition economies: a conceptual model. In Developmental Entrepreneurship: Adversity, Risk, and Isolation (pp. 89-111). Emerald Group Publishing Limited.

Souitaris, V., Zerbinati, S., \& Al-Laham, A. (2007). Do entrepreneurship programmes raise entrepreneurial intention of science and engineering students? The effect of learning, inspiration and resources. Journal of Business venturing, 22(4), 566-591.

Wang, C. K., \& Wong, P. K. (2004). Entrepreneurial interest of university students in Singapore. Technovation, 24(2), 163-172.

Williams, N., \& Williams, C. C. (2014). Beyond necessity versus opportunity entrepreneurship: some lessons from English deprived urban neighbourhoods. International Entrepreneurship and Management Journal, 10(1), 23-40.

Wilson, F., Kickul, J., \& Marlino, D. (2007). Gender, entrepreneurial self-efficacy, and entrepreneurial career intentions: Implications for entrepreneurship education. Entrepreneurship Theory and Practice, 31(3), 387-406.

Wu, S., \& Wu, L. (2008). The impact of higher education on entrepreneurial intentions of university students in China. Journal of Small Business and Enterprise Development, 15(4), 752-774. 